\title{
Moderating Impact of Ownership Structure on Relationship of Equity Market Timing with Capital Structure on Companies Listed on Indonesia Stock Exchange
}

\author{
Irni Yunita \\ Universitas Padjadjaran, Indonesia \\ Irniyunita81@yahoo.com \\ Rina Indiastuti \\ Universitas Padjadjaran, Indonesia \\ rina.indiastuti@fe.unpad.ac.id \\ Ria Ratna Ariawati \\ Universitas Padjadjaran, Indonesia \\ ria@unikom.ac.id \\ Erie Febrian \\ Universitas Padjadjaran, Indonesia \\ Erie.Febrian@unpad.ac.id
}

\begin{abstract}
The purpose of this research is to determine the effect of market to book ratio on leverage change with ownership structure as moderating variable. The research sample is 41 companies in Indonesia Stock Exchange which conducted IPO in 2005 - 2010. The analysis period is five years after an IPO. The independent variable is market to book ratio, the dependent variable is leverage change and control variable is tangibility, profit and size. The moderating variables are managerial and institutional ownerships which included as ownership structure. This research is using data panel regression. The results show that companies in Indonesia pursued the equity market timing strategy because there is a positive effect of market to book ratio into equity issue and negative effect of market to book ratio into leverage change. The results also show that institutional ownership structure moderating the equity market timing. However, managerial ownership does not moderating the equity market timing.
\end{abstract}

Keywords: Equity Market Timing, Managerial Ownership, Institutional Ownership.

\section{Introduction}

Equity Market Timing theory, a theory of capital structure which first proposed by Baker and Wurgler (2002), connects the market value of the company to the funding policy. According to Baker and Wurgler (2002), the company pursues the equity market timing strategy by issuing shares when the company's market value is high; and on the contrary, the company sells the shares when the market value is low. The reason is when the market value is high, the cost of equity acquired is low, and vice versa; therefore, the company can get a lower cost of equity capital. Baker and Wurgler implement market to book ratio variable as an indicator of market value which may affect the capital structure. 
The results show that there is a negative and significant influence of market to book ratio to leverage changes which means the higher value of market to book ratio, the lower the company's leverage. Furthermore, Baker and Wurgler (2002) analyse the effect of market to book ratio to the components of leverage changes, i.e. debt issuance, retained earnings and the issuance of net shares. The results show that the market to book ratio has negative and insignificant effect on the issuance of debt; positive and insignificant effect on the retained earnings; and positive and significant effect of the issuance of new shares. It shows that the companies pursue the equity market timing strategy because of the leverage changes dominated by issuing new shares based on the market valuation.

In Indonesian Stock Exchange, the companies can pursue the equity market timing strategy in their funding policy since the mispricing, the difference between the market value with the company value, commonly happens. It can be seen from the Market to Book Ratio (MB) presented in Figure 1.

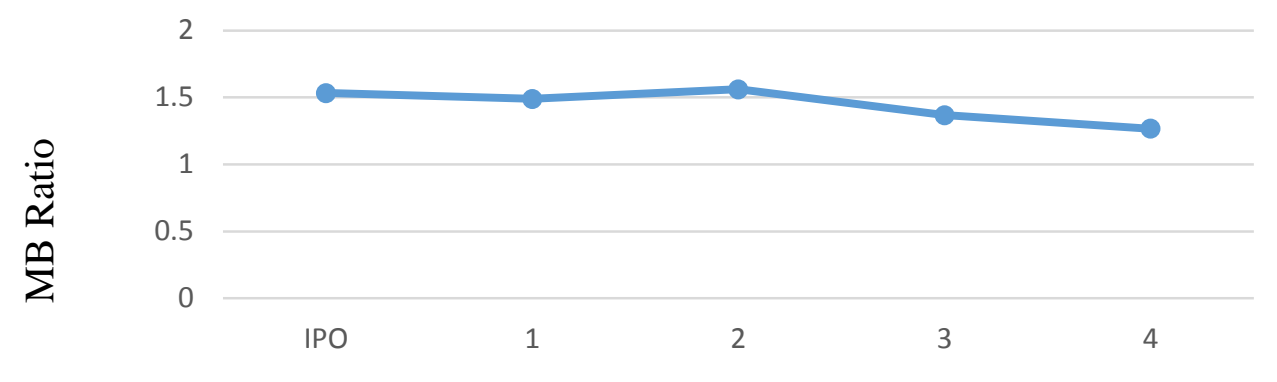

Figure 1. The Movement of Average of Market to Book Ratio Source: Data Analysis (2018)

Figure 1 shows mispricing where the average market to book ratio of the company is more than 1. Moreover, it is also shown that the issuance of shares follows the increase in market to book value from the previous period. This situation can be taken into benefit by the companies in pursuing equity market timing strategy in order to determine funding policy.

Some researches, such as Huang and Ritter (2005), Chicti and Bougatef (2010), Susilawati (2012), Hunafa and Nugroho (2014), and Ma and Rath (2016), support the equity market timing theory. However, the study by Taurisina (2013) shows different results in which the market to book ratio has a positive effect on leverage. In addition, the research results from Hunafa and Nugroho (2014) indicates that the market to book ratio is negatively related to the issuance of net share.

The researches on the equity market timing do not show consistent results. It is likely possible since the model of Baker and Wurgler (2002) is unconditional on the condition of the company or other factors that determine and motivate the equity market timing. The companies that do not do the equity market timing may not focus on the external funding such as the issuance of shares. Capital structure in Indonesia, in general, has a policy of high debt usage (Nurdin, 2016) which leads to the use of debt to be the major source of company funding. Babu and Jain (1998) as quoted by Rokhman (2015) state that there are four reasons why companies prefer employing debt to new shares, namely: (1) the existence of tax benefits of interest payments, (2) the debt cost is much cheaper than the transaction costs, (3) 
easier access to debt financing than stock financing, and (4) greater management control of new debt than new shares.

In addition, by not doing market timing, it can be said that the manager is not able to take advantage of valuable stocks overvalued by issuing equity in the capital market. In fact, the manager has an ability to recognize the mispricing situations and utilize them to get a low cost of capital when the share price is overvalued. It is likely possible due to the company's financial difficulties, high cost of share issuance and ownership structure.

Financial constraints may weaken the effect of equity market timing to capital structure. The study conducted by Saad and Siagian (2011) proves the financial constraints weakens the equity market timing practices. The companies experiencing financial constraints will face difficulty to have access to external funding sources and will lead to the opportunities to do equity market timing cannot be realized. Furthermore, the issuance costs of shares could undermine the equity market timing since the transaction cost of debt expense is cheaper than the transaction cost of new share issuance (Rokhman, 2015). This situation causes the companies prefer debt to the issuance of new shares in trying to find the additional funds for the company. Share ownership structure could either strengthen or weaken the equity market timing since share ownership shows control over the company which determines the policy of company's funding sources. The decisions concerning on the funding policy are determined through a general meeting of shareholders in order the funding decisions to be able to be affected by the percentage of stock ownership in a company.

This study aims to re-examine the equity market timing using the dependent variable as in research conducted by Baker and Wurgler (2002), i.e. leverage changes by including other factors that motivate the company to undertake equity market timing, in this case, the ownership structure as moderating variables that can strengthen and weaken the equity market timing pursued by the company. According to Jensen and Meckling (1976), the ownership structure is used to indicate that the funding decision is not only determined by the amount of debt and equity, but also by the percentage of ownership by managers and institutional investors. Therefore, the ownership structure can influence decisions of funding sources whether through debt or the issuance of shares. There are two types in the structure of ownership and control of the company, namely: (1) the company is owned by many shareholders and controlled by management, and (2) the company is owned and controlled by non-management, such as institution (Mathiesen, 2014). During the study, the average managerial ownership was 7\%, while the institutional ownership was $65 \%$.

Managerial ownership is the amount of share ownership by the company management as measured by the percentage of total shares owned by the management (Sujoko \& Soebiantoro, 2007). With share ownership in the company, managers can also determine the direction of company policy through various existing mechanisms as the company owners, such as general meeting of shareholders and active participation of shareholders to the company including buying, holding and issuing shares (Nurdin, 2016). Furthermore, Kurniasari in Wiryani and Mertha (2016) states that managerial ownership is intended to give managers an opportunity to be involved in share ownership in order to make the manager's position is equal to the owner of the company. The managerial 
ownership will transfer the control of the company to the manager (Jensen \& Meckling, 1976).

Wiryani and Mertha (2016) state that managerial ownership is able to influence the company's businesses which will eventually affect the capital structure. Regarding to its effect on one of the capital structure components, i.e. the issuance of shares, managerial ownership may influence the decision of issuance of new shares (Haruman, 2008). The manager can take the equity market timing to determine the exact time when they will issue shares since the manager has the ability to recognize mispricing conditions occurring in the capital market (Baker et al, 2007) in Saad and Siagian (2011). Therefore, under mispricing condition, the manager will be interested in issuing shares to collect funds instead of using debt since the cost of equity is lower when the share price is high. Moreover, it is described in agency theory that the higher managerial ownership, the more cautious the managers will be in using debt (Wiryani \& Mertha, 2016) since the increasing amount of debts will cause financial distress (Rahmayani, 2008). Financial distress will lead to a reduction of the company value as well as the prosperity of the owners (Sudjoko \& Soebiantoro, 2007).

The empirical evidence on the relationship between managerial ownership and funding decisions is shown by Friend and Lang (1988) and Jensen et al. (1992). They show that the use of debt will decrease as the managerial ownership in the company increases. According to Huang et al. (2009), high managerial ownership is able to overcome the agency conflict between the interests of management with shareholders since the management also acts as shareholders. Therefore, the managerial interests can be in line with the interests of shareholders in maximizing the company value. It can raise the level of trust from the investors to the managers in managing the funds that have been invested. The increasing level of investor's trust can be seen from the decrease in the cost of equity debt at the time of managerial ownership increased (Huang et al., 2009).

Based on the aforementioned explanation, it is possible that high managerial ownership can strengthen funding through the issuance of shares. As a result, there is a presumption that managerial ownership reinforces the negative influence of the market to book ratio to the level of leverage changes.

Institutional ownership is an ownership by the government, financial institutions, institutional legal entities, foreign institutions, trust funds and other institutions at the end of the year (Widigdo, 2013). In the companies in Indonesia, during this study, the average institutional ownership was $65 \%$. This percentage is quite large in determining company policy, one of which is the funding policy.

Institutional investors play an active role in monitoring the management of the company so that the management is encouraged to improve the company performance. Badriyah (2015) shows that the large number of percentage of institutional shareholding will be able to reduce the agency theory and the power of votes; furthermore, the impetus of financial institution will be greater to oversee the management and consequently will give greater impetus to optimize the company value. As a result, it will improve the company's financial performance.

The increase of company performance leads the risk of companies to be smaller and force the return desired by the creditor becomes lower. Therefore, greater institutional ownership will make it easier to access funding through debts. 
According to Mehran (1992) in Susilawati (2007) states that the substantial control of the institution leads managers to be able to make the investments better and need for additional funds through debts. Rahmayani (2008) shows that institutional ownership has a significant relationship to funding decisions. Moreover, institutional ownership has a positive relationship to leverage the company (Crutchley et al. (1999) and Indahningrum and Hand (2009) in Rokhman (2015)). These show that the higher the institutional ownership, the higher the use of debt in the structure of a company's funding. Mahmudi (2008) shows that the company with high institutional ownership structures tends to issue fewer shares.

Based on the aforementioned explanation, it is likely possible that high institutional ownership can undermine the funding through the issuance of shares. It means there is a presumption that weakens the negative influence of the market to book ratio to the level of leverage changes.

Different from previous studies, this study will use the ownership structure as moderating variable. The use of ownership structure, managerial and institutional ownerships, as moderating variables, has not been conducted in several previous researches in Indonesia. Therefore, this study is conducted to analyse the effect of equity market timing to capital structure of the companies in Indonesia with ownership structure which consists of managerial and institutional ownership as moderating variable.

\subsection{Statement of Problems}

1) Is there an effect of market to book ratio to equity issue?

2) Is there an effect of market to book ratio to leverage change?

3) Does the managerial ownership structure moderating the influence of market to book ratio to the level of leverage changes?

4) Does the institutional ownership structure moderating the influence of market to book ratio to the level of leverage changes?

\section{Literature Review}

\subsection{Equity Market Timing Theory}

Equity Market Timing theory is proposed by Baker and Wurgler (2002). This theory uses market value as one of the main factors that may affect the capital structure. This theory states that the company's capital structure is the cumulative results of an effort to make the equity market timing in the past where the company will issue equity at the time of high market value and buy back the equity at the time of low market value.

Baker and Wurgler use the leverage change and the issuance of net shares the dependent variables and use the market to book ratio as an indicator of market timing and use control variables such as: Asset tangibility, TANG (Fixed Asset/Total Asset), Profitability, PROFIT (EBIT/Total Asset) and Company Size, SIZE (Ln Sales) (Rajan \& Zingales, 1995). The formulas of Leverage Change, Net Equity Issue and Market to Book ratio are:

$$
\text { DLTBLEV }=\left(\frac{D}{A}\right)_{\mathrm{t}}-\left(\frac{D}{A}\right)_{\mathrm{t}-1}
$$

DLTBLEV: Leverage Changes 
D: Total Debt

A: Total Assets

$$
\text { NET EQUITY }=\left(\frac{\Delta \text { book equity }-\Delta \text { retained earning }}{\text { Total Asset }}\right)
$$

NET EQUITY: Issuance of Shares Net

$$
\text { Market to book ratio }=\frac{\text { Assets }- \text { Book equity }+ \text { Market equity }}{\text { Assets }}(3)
$$

Market to book ratio may indicate the ability of management to improve the welfare of its shareholders perceived from the market value. If this ratio is not equal to 1 , there is a difference between the share price and the book value of the company; it is called mispricing. During mispricing condition, companies can take the opportunity to sell their shares several times above its book value. Conversely, companies can take the opportunity to buy back the shares of the company at the time when the market value is below its book value.

\subsection{Ownership Structure}

Jensen and Meckling (1976) suggest that ownership structure is used to indicate that the funding decision is not only determined by the amount of debt and equity, but also by the percentage of ownership by managers and institutional investors. As a result, it can influence funding decision whether through debt or the issuance of shares. There are two types in ownership structure and company control, namely: (1) the company is owned by many shareholders and controlled by management, and (2) the company is owned and controlled by non-management, such as institution (Mathiesen, 2014).

\subsection{Managerial Ownership}

Managerial ownership is the amount of share ownership by the company management as measured by percentage of total shares owned by the management (Sujoko \& Soebiantoro, 2007). With share ownership in the company, managers can also determine the direction of company policy through various existing mechanisms as company owners, such as general meeting of shareholders and active participation of shareholders to the company actively including buying, holding and issuing shares (Nurdin, 2016). Furthermore, Kurniasari in Wiryani and Mertha (2016) states that managerial ownership is intended to give managers an opportunity to be involved in share ownership in order to make the manager's position is equal to the owner of the company. The managerial ownership will transfer the control of the company to the managers (Jensen \& Meckling, 1976).

Wiryani and Mertha (2016) state that managerial ownership is able to influence the company's businesses which will eventually affect the capital structure. Regarding to its effect on one of the capital structure components, i.e. the issuance of shares, managerial ownership may influence the decision of issuance of new shares (Haruman, 2008). The manager can take the equity market timing to determine the exact time when they will issue shares since the manager has the ability to recognize mispricing conditions occurring in the capital market (Baker et al, 2007 in Saad and Siagian (2011). Moreover, it is described in agency theory that the higher managerial ownership, the more cautious the managers will be in using debt (Wiryani \& Mertha, 2016) since the increasing amount of debts will cause financial distress (Rahmayani, 2008). 
The empirical evidence on the relationship between managerial ownership and funding decisions is shown by Friend and Lang (1988) and Jensen et al. (1992). They show that the use of debt will decrease as the managerial ownership in the company increases. According to Huang et al. (2009), high managerial ownership is able to overcome the agency conflict between the interests of management with shareholders since the management also acts as shareholders. Therefore, the managerial interests can be in line with the interests of shareholders in maximizing the company value. It can raise the level of trust from the investors to the managers in managing the funds that have been invested. The increasing level of investor's trust can be seen from the decrease in the cost of equity debt at the time of managerial ownership increased (Huang et al., 2009).

Friend and Lang (1988) suggest that the level of debt will decrease when the managers' share ownership increases. Managerial ownership is a shareholder from the management parties which actively participate in the company decision, namely directors and commissioners (Susilawati, 2007). Managerial ownership can be formulated as follows:

$$
\text { Managerial Ownership }(K M)=\frac{\text { Managerial ownership share }(S M)}{\text { Outstanding share }(S B)} \times 100 \%
$$

\subsection{Institutional Ownership}

Institutional ownership is an ownership by the government, financial institutions, institutional legal entities, foreign institutions, trust funds and other institutions at the end of the year (Widigdo, 2013). Institutional investors play an active role in monitoring the management of the company so that the management is encouraged to improve the company performance. Badriyah (2015) shows that the large number of percentage of institutional shareholding will be able to reduce the agency theory and the power of votes; furthermore, the impetus of financial institution will be greater to oversee the management and consequently will give greater impetus to optimize the company value. As a result, it will improve the company's financial performance.

The increase of company performance leads the risk of companies to be smaller and force the return desired by the creditor becomes lower. Therefore, greater institutional ownership will make it easier to access funding through debts. According to Mehran (1992) in Susilawati (2007), the substantial control of the institution leads managers to be able to make the investments better and need for additional funds through debts. Rahmayani (2008) shows that institutional ownership has a significant relationship to funding decisions. Moreover, institutional ownership has a positive relationship to leverage the company (Crutchley et al. (1999) and Indahningrum and Hand (2009) in Rokhman (2015)). These show that the higher the institutional ownership, the higher the use of debt in the structure of a company's funding. Furthermore, the addition of debts in the capital structure can reduce the use of shares. Institutional ownership can be formulated as follows:

$$
\text { Institutional Ownership }(K I)=\frac{\text { Institutional ownership share }(S I)}{\text { Outstanding share }(S B)} \times 100 \%
$$

The hypotheses of this study are as follows:

Hypothesis 1: There is a positive effect of market to book ratio to equity issue. 
Hypothesis 2: There is a negative effect of market to book ratio to the level of leverage changes.

Hypothesis 3: Managerial ownership moderates the effect of market to book ratio to the level of leverage changes.

Hypothesis 4: Institutional ownership moderates the effect of market to book ratio to the level of leverage changes.

\section{Research Method}

The sample of this study is 41 non-financial companies that conduct IPO at a particular time between 2005 to 2010 at Indonesia Stock Exchange. The analysis period is five years after IPO. The dependent variables in this study are the level of leverage changes and equity issue. Meanwhile, the independent variable in this study is the market to book ratio. The moderating variables are managerial ownership and institutional ownership. In addition, this research is using control variables which are tangibility, profitability and size.

This research is using data panel regression model to analyse the impact of ownership to the relation between market to book ratio and leverage change. The model is as follows:

$1^{\text {st }}$ Model: The Impact of Market to Book Ratio to Equity Issue.

$\left(\frac{e}{A}\right)_{i t}=\beta_{0}+B_{1}\left(\frac{M}{B}\right)_{i t-1}+B_{2}\left(\frac{P P E}{A}\right)_{i t-1}+B_{3}\left(\frac{E B I T}{A}\right)_{i t-1}+B_{4} \log (S)_{i t-1}+e_{t}$

$2^{\text {nd }}$ Model: The Impact of Market to Book Ratio to Leverage Change.

$D_{L T B L E V}{ }_{i t}=\beta_{0}+A_{1}\left(\frac{M}{B}\right)_{i t-1}+A_{2}\left(\frac{P P E}{A}\right)_{i t-1}+A_{3}\left(\frac{E B I T}{A}\right)_{i t-1}+A_{4} \log (S)_{i t-1}+A_{5}\left(\frac{L T D}{A}\right)_{i t-1}+e_{t}$

$3^{\text {rd }}$ Model: Managerial Ownership moderating the relation between Market to Book Ratio and Leverage Change.

$\begin{aligned} D L T D B L E V_{i t}= & \beta_{0}+C_{1}\left(\frac{M}{B}\right)_{i t-1}+C_{2}\left(\frac{M}{B}\right)_{t-1}\left(\frac{S M}{S B}\right)_{i t-1}+C_{3}\left(\frac{P P E}{A}\right)_{i t-1}+C_{4}\left(\frac{E B I T}{A}\right)_{i t-1}+C_{5} \log (S)_{i t-} \\ & +e_{t}\end{aligned}$

$4^{\text {th }}$ Model: Institutional Ownership moderating the relation between Market to Book Ratio and Leverage Change.

$D L T B L E V_{i t}=\beta_{0}+D_{1}\left(\frac{M}{B}\right)_{i t-1}+D_{2}\left(\frac{M}{B}\right)_{i t-1}\left(\frac{S I}{S B}\right)_{i t-1}+D_{3}\left(\frac{P P E}{A}\right)_{i t-1}+D_{4}\left(\frac{E B I T}{A}\right)_{i t-1}+D_{5} \log (S)_{i t-}$

$1+e_{t}$ 


\section{Result and Discussion}

From table 4.1, $2^{\text {nd }}$ Model, it can be seen that MB variable significantly affect the equity issue with hypothesis result of $\alpha=0.01$; Asset tangibility (TANG), profitability (PROFIT) and company size (SIZE) show insignificant results. Table 4.1, $1^{\text {st }}$ Model shows that market to book ratio (MB) variable leads to significant result of the hypothesis of $\alpha=0.05$; therefore, it can be concluded that there is a significant effect of MB variable to the leverage change. Asset tangibility (TANG), and company size (SIZE) variables showed insignificant result.

From the statistical test result (1) and (2), it can be concluded that the companies pursue the equity market timing strategy in issuing shares and it affects their capital structure.

Table 4.1 The Effect of Market to Book Ratio to the Level of Leverage Changes and Net Equity Issue

\begin{tabular}{|c|c|c|}
\hline Variable & $\mathbf{1}^{\text {st }}$ Model & $\mathbf{2}^{\text {nd }}$ Model \\
\hline MB & $0.03^{* * *}$ & $-0.017^{* * *}$ \\
& $(0.002)$ & $(0.04)$ \\
& 0.05 & -0.03 \\
& $(0.14)$ & $(0.61)$ \\
\hline TANG & $-0.18^{* *}$ & 0.10 \\
& $(0.07)$ & $(0.28)$ \\
\hline PROFIT & 0.003 & 0.003 \\
& $(0.56)$ & $(0.83)$ \\
\hline SIZE & & $-0.70 * * *$ \\
& & $(0.00)$ \\
\hline LTBLEVT_1 & & \\
& & \\
\hline
\end{tabular}

Source: Writer's Data Analysis Result (2018)

\subsection{Moderation of Managerial Ownership on the Effect of Market to Book Ratio to the Leverage Changes}

From Table 4.2, it shows that the interaction variable between $\mathrm{MB}$ and $\mathrm{KM}$ (MB_KM) gives a hypothetical result that is significant at $\alpha=0.05$. The MB_KM coefficient of -0.064057 which is negative and significant means that the higher the moderation of managerial ownership, the negative effect of $\mathrm{MB}$ on changes in leverage level will increase. Table 4.2 also shows the R-Squared value of $46.30 \%$, higher than $46.12 \%$ (R-Squared value in Table 4.10) before entering managerial ownership variables as moderating variables.

Table 4.2 T-test Statistic Result of Research Hypotheses (3) 


\begin{tabular}{|c|c|c|c|}
\hline Variable & $\begin{array}{c}\text { Coefficient Before } \\
\text { Adding } \\
\text { Managerial } \\
\text { Ownership } \\
\left(2^{\text {nd }} \text { Model }\right)\end{array}$ & $\begin{array}{l}\text { Coefficient After } \\
\text { Adding Managerial } \\
\text { Ownership } \\
\left.\text { (3 }{ }^{\text {rd }} \text { Model }\right)\end{array}$ & $\begin{array}{l}\text { Probability } \\
\text { After Adding } \\
\text { Managerial } \\
\text { Ownership }\end{array}$ \\
\hline MB & $-0.017 * *$ & -0.004 & 0.6324 \\
\hline MB_KM & - & $-0.064 * *$ & 0.0270 \\
\hline TANG & -0.03 & $0.109 *$ & 0.0790 \\
\hline PROFIT & 0.103 & 0.145 & 0.1340 \\
\hline SIZE & 0.003 & $-0.062 * * *$ & 0.0003 \\
\hline LTBLEVT_1 $_{-1}$ & $-0.705 * * *$ & 0.688 & 0.0000 \\
\hline R-Squared & 0.461246 & \multicolumn{2}{|c|}{0.463049} \\
\hline Prob (F-statistic) & 0.000000 & \multicolumn{2}{|c|}{0.000000} \\
\hline N (Sample Size) & 41 & \multicolumn{2}{|l|}{41} \\
\hline Period & 5 & \multicolumn{2}{|l|}{5} \\
\hline
\end{tabular}

Source: Writer's Data Analysis Result (2018)

Hypothesis 3 (H3) states that managerial ownership reinforces the influence of last year's negative MB ratio on changes in leverage. The results show that the presence of managerial ownership variables caused no significant influence from the market to book ratio on changes in leverage. From the results of the statistical test analysis in Table 4.2, the managerial ownership coefficient has a positive and significant effect on changes in leverage. This shows that the higher managerial ownership will further increase leverage changes so that the existence of managerial ownership variables causes the absence of market timing equity. This is not in accordance with the results of research from Fried and Lang (1988) which states that the use of debt will decrease with increasing managerial ownership in the company. The results of the study are also not in accordance with the results of research from Jensen et al. (1992), Mohd et al. (1998), Bathala et al. (1994), Wahidahwati (2002) and Tarjo (2003), Huang et al. (2009) and Sheisarvian et al. (2015) which shows that there is a negative relationship between managerial shareholding structure and debt level. According to Jensen and Meckling (1976), if managers have high share ownership in the company, they will reduce the level of debt usage optimally, so that it will reduce the agency cost of debt because it can align the interests of the owner of the company with the interests of managers. The increase in share ownership by managerial parties will make managers more careful in using debt and minimize the risk posed because the manager feels he owns the company. This can happen because the manager will feel the direct benefit of every decision taken and loss if the decision taken is wrong. Thus, according to agency theory, the higher share ownership held by managerial parties, the debt that will be used by a company will be lower.

But if managerial ownership variables interact with the market to book ratio, then the interaction variable can significantly negatively affect the change in leverage 
which seen from the coefficient that shows a negative and significant value. The results of this study support the results of research from Graham and Harvey (2001) which states that most managers agree that market value is an important factor in issuing shares. Therefore, when last year's MB ratio was high, managers took advantage of the increase in the MB ratio last year in issuing shares.

\subsection{Moderation of Institutional Ownership on the Effect of Market to Book Ratio to the Leverage Changes}

From Table 4.3 shows that the market to book ratio variable gives the results of a hypothesis that is significant at a negative and significant effect on changes in leverage. This shows that there is a market timing equity. Interaction institutional ownership variable (KINS) and market to book ratio (MB_KINS) give significant hypothetical results at $\alpha=0.05$ so that Ho is accepted. This shows that institutional ownership moderates the effect of $\mathrm{MB}$ on changes in leverage levels significantly. The value of R-Squared in the hypothesis 4 is $48.27 \%$, which means that $48.27 \%$ variation in leverage changes is explained by variations in the independent variables and the remaining $51.73 \%$ is influenced by other variables.

Table 4.3 T-test Statistic Result of Research Hypotheses (4)

\begin{tabular}{|c|c|c|c|}
\hline Variable & $\begin{array}{c}\text { Coefficient Before } \\
\text { Adding } \\
\text { Institutional } \\
\text { Ownership } \\
\left(2^{\text {nd }} \text { Model }\right)\end{array}$ & $\begin{array}{c}\text { Coefficient After } \\
\text { Adding } \\
\text { Institutional } \\
\text { Ownership } \\
\left.\text { (4 }{ }^{\text {rd }} \text { Model }\right)\end{array}$ & $\begin{array}{l}\text { Probability } \\
\text { After Adding } \\
\text { Institutional } \\
\text { Ownership }\end{array}$ \\
\hline MB & $-0.017 * *$ & $-0.060 * * *$ & 0.0016 \\
\hline MB_KINS & - & $0.073^{* *}$ & 0.0113 \\
\hline TANG & -0.03 & -0.023 & 0.6961 \\
\hline PROFIT & 0.103 & 0.098 & 0.3010 \\
\hline SIZE & 0.003 & 0.011 & 0.5102 \\
\hline LTBLEVT_1 & $-0.705 * * *$ & $-0.695104 * * *$ & 0.0000 \\
\hline R-Squared & 0.461246 & \multicolumn{2}{|c|}{0.482769} \\
\hline Prob (F-statistic) & 0.000000 & \multicolumn{2}{|c|}{0.000000} \\
\hline N (Sample Size) & 41 & \multicolumn{2}{|c|}{41} \\
\hline Period & 5 & \multicolumn{2}{|l|}{5} \\
\hline
\end{tabular}

Source: Writer's Data Analysis Result (2017)

Hypothesis 4 (H4) states that institutional ownership weakens the influence of MB ratio on changes in leverage. The results of statistical test analysis in Table 4.3 show that the MB variable coefficient has a significant effect on changes in leverage with a negative direction which means that the company carries out market timing equity in which when the market to book ratio increases, it can reduce changes in leverage. This means proving the proposed hypothesis that the greater MB will be able to 
reduce the company's leverage. The significance value obtained is 0.01 with $\alpha=$ 0.01 .

Table 4.3 shows the influence of MB ownership on changes in leverage that are moderated by institutional ownership (KINS). The results show that KINS is able to moderate $\mathrm{MB}$ by minimizing the influence of $\mathrm{MB}$, thereby increasing company leverage. When institutional ownership is able to reduce the influence of MB on leverage, it means proving the hypothesis proposed that the greater KINS will be able to weaken the occurrence of market timing equity. The significance value obtained is 0.05 with $\alpha=0.05$.

According to Crutchley et al. (1999) and Indahningrum and Handayani (2009) in Rokhman (2015), the institutional ownership structure has a positive relationship to company leverage so the higher institutional ownership, the higher the use of debt in the funding structure of a company. With the increasing ownership structure, companies tend to issue fewer shares (Mahmudi, 2008). Institutional investors play an active role in monitoring company management so that management is encouraged to improve company performance. The results of the study from Badriyah (2015) indicates that the percentage of institutional share ownership in large numbers will be able to reduce agency costs and the greater the power of voice and the encouragement of financial institutions to oversee management and consequently will provide greater impetus to optimize company value so that improve the company's financial performance. Increasing company performance makes the company's risk smaller so that the return desired by creditors is lower. Therefore, the greater institutional ownership facilitates access to funding through debt; the higher the ownership structure will be able to reduce the use of funds through the issuance of shares.

\section{Conclusion}

The results showed that: (1) there is an effect of market to book ratio to equity issue thus it can concluded that the company in Indonesian Stock Exchange conducts equity market timing, (2) there is an effect of equity market timing to leverage change, (3) managerial ownership does not moderates the effect of market to book ratio to the level of leverage changes, and (4) institutional ownership moderate the effect of equity market timing to the level of leverage changes.

There are several suggestions for the next studies, which are the next researchers need to extend the research period, analyse equity market timing in each sector of the company, use other market value variables other than the market to book ratio such as price to book value, and use other types of ownership structures such as the family ownership structure. 


\section{References}

Baker, M., \& Wurgler, J. (2002). Market Timing and Capital Structure. Journal of Finance, 57, 1-32.

Chichti, J., \& Bougatef, K. (2010). Equity Market Timing and Capital Structure : Evidence From Tunisia and France. International Journal of Business and Management, 5(10).

Friend, I., \& Lang, L. (1988). An Empirical Test of Managerial Self Interest on Corporate Capital Structure. Journal of Finance, 43(2), 271-281.

Graham, J., \& Harvey, C. (2001). The Theory and Practice of Corporate Finance : Evidence from The Field. Journal of Financial Economics, 60, 187-243.

Haruman, T. (2008). Pengaruh Struktur Kepemilikan terhadap Keputusan Pendanaan (Perspektif Agency Theory) : Survey pada Perusahaan Manufaktur di Bursa Efek Indonesia. National Conference on management Research.

Huang, H., Wang, Q., \& Zhang, X. (2009). The effect of CEO ownership and shareholder rights on cost of equity capital. Corporate Governance: The international journal of business in society, 9(3), 225-270.

Huang, R., \& Ritter, J. (2005). Testing the Market Timing of Capital Structure. Working Paper from University of Florida, 1-44.

Hunafa, A., \& Nugroho, B. Y. (2014). Pengaruh Market Timing terhadap Struktur Modal Perusahaan yang melakukan Penawaran Saham Perdana (IPO) yang tercatat di BEI. Depok: Universitas Indonesia.

Jensen, M. C., \& Meckling, W. (1976). Theory of the Firm : Managerial Behavior, Agency Costs and Ownership Structure. Journal of Financial Economics, 3(4), 305-360. Retrieved from http://papers.ssrn.com

Ma, S., \& Rath, S. (2016). Market Timing of New Equity Offerings: Evidence from Chinese Listed Firms. Australasian Accounting, Business and Finance Journal, 10(2).

Mathiesen, H. (2014). Struktur Kepemilikan dan Kinerja. Retrieved from http://encycogov.com.

Nurdin. (2016). Intervensi Pemegang Saham Dalam Pembuatan Keputusan Pendanaan (Studi Empiris pada Perusahaan Non Keuangan di Bursa Efek Indonesia. Bandung: Universitas Padjadjaran.

Rahmayani, H. N. (2008). Pengaruh Kepemilikan Institusional dan Karakteristik Keuangan Terhadap Keputusan Pendanaan. Semarang: Universitas Diponegoro.

Rajan, R. G., \& Zingales, L. (1995). What Do We Know About Capital Structure? Some Evidence from International Data. Journal of Finance 39, 575-592. 
Rokman, M. T. (2015). Pengaruh Kepemilikan manajerial, Kepemilikan Institusional dan Ukuran Perusahaan terhadap Kebijakan Hutang Perusahaan Manufaktur di Bursa Efek Indonesia. Manajemen dan Bisnis Jurnal, 1(2).

Saad, M. D., \& Siagian, H. (2011). Sentimen Investor, Kendala Keuangan, dan Equity Market Timing. Finance and Banking Journal, 13(1).

Soebiantoro, S. d. (2007). Pengaruh Struktur Kepemilikan Saham, Leverage, Faktor Intern dan Faktor Ekstern Terhadap Nilai Perusahaan (Studi Empirik pada Perusahaan Manufaktur dan non Manufaktur yang Terdaftar di Bursa Efek Jakarta). Jurnal Manajemen dan Kewirausahaan.

Susilawati, E. (2012). Implikasi Market Timing terhadap Struktur Modal Perusahaan. Jurnal Manajemen, 16(1).

Taurisina, A. M. (2013). Pengaruh Market Timing Theory terhadap Struktur Modal Perusahaan Non-Keuangan di Indonesia. Yogyakarta: Universitas Gajah Mada.

Widigdo, I. (2013). Effect of Corporate Social Performance, Intellectual Capital, Ownership Structure, and Corporate Governance on Corporate Performance and Firm Value (Studies on Companies Listed in The Sri Kehati Index). International Journal of Business, Economics and Law, 2(1).

Wiryani, D. A., \& Mertha, I. M. (2016). Kepemilikan Manajerial sebagai Pemoderasi Pengaruh Diversifikasi Operasional pada Struktur Modal. EJurnal Akuntansi Universitas Udayana, 15(3). 